\title{
Strategies for the identity of sustainable suburbs
}

\author{
R. Barelkowski \\ West-Pomeranian University of Technology in Szczecin, Poland
}

\begin{abstract}
The paper discusses the managing of a multiplicity of factors affecting the character of the city and at the same time analyzes three various approaches to suburban areas to compare their methodological guidelines and addresses the issue of urban identity within sustainability (on a strategic level). These approaches focus on the identity problem of a suburban area, extending the instrumental background provided by the framework established earlier for peripheral urban zones in Poland. Strategies are confronted with 3 distinct applications around the city of Poznan.
\end{abstract}

Keywords: spatial planning, sustainability, suburbs.

\section{Introduction}

A simplified approach to municipal structures allows us to distinguish their historical core, a spatial anchor and focal point for all emerging new contents of urban agglomeration, new districts, suburbs, related landscape surrounding the city. The core is often determined, renewing itself in processes of refurbishment or regeneration. While the downtown of urban agglomeration focuses the interest of authorities, at the same time it is supposed to attract investors, external areas of the city are much more diversified, and the impact they have on the whole urban structure depend on multiple factors, making even neighboring districts different, of distinct potential. The potency of the city is therefore determined not by the downtown or suburbs alone, but by the combination - dynamic interactions between the two [1, p. 759]. It is therefore fundamental to treat those areas as "partners", to manage the fragile balance between an apparently stronger center and seemingly weaker peripheral area. 
The seam between urban and rural areas, in times of dynamic urbanization and inflation of municipal areas, ceased to be gradual and harmonious [2]. Suburban zones are places of mixed character, delivering places that could typically belong to the central parts of the city, isolated post-development detached, semi-detached or row housing ghettos, chaotic individual housing (mainly detached houses spreading randomly around the area, without any appropriate sequence of construction), storage, transport or production/logistics facilities, low quality or lack of public space are only rarely replaced with open and organized structures sometimes housing, particularly mixed with ground floor service and commercial space, sometimes commercial/retail. Both the size of urban complex as well as fluctuations of function and meaning within urban complex allowed to form these local sub-centers, but still urban sprawl defines the majority of peripheral areas of cities.

This paper aims to discuss the problem of building strategy for suburbs. It uses the framework provided describing the instrumental aspect of strategy implementation - the field of organization of strategy. This time however, the establishing of strategy focuses on building the identity. Spatial (urban) identity is herein understood as basic anchor to create the potential of suburban area to diversify the autonomy of urban components - to allow these components to absorb more efficiently unavoidable coming transformations.

Cultural dependency between various areas of a city form common network of ties binding the urban structure together [3], those basic functions and respectfully basic level of social and economic activity of municipal life is expected to provide certain autonomy to establish the basis for sustainable development for the particular suburban area [4]. This is where general features can be distinguished from unique properties of suburban space and set of these properties recognized together can be helpful in determining sustainable strategies for outer districts of the city.

\section{Place for strategy: strategy within system}

The process of urban sprawl is still, contemporarily, one of the most significant issues related to the condition urban areas perform. Savitch notices, that sprawl has long been a major and largely uncontrolled force reshaping cities all over the world and that this tendency cannot be easily contained [5]. Its results remain significantly negative regardless of the site, despite the differences between nations organizing their urban life within strict limitations of overdeveloped Europe and America having much space for expansion. No longer does urban space play the role of a fixed site to which communities may attach certain functions - it becomes a vessel for social actions and interactions, altering not only the notion of urban space, but transforming the way cities are managed and affecting the application of professional knowledge in spatial planning and urban as well as architectural design [6]. Building the structure of the city no longer is decided in physical space, where particular components are attributed to the site. Instead mental (common, social) representation of the city becomes a blueprint 
studied to manifest physical structure capable of making the city livable [7, pp. 1722].

The problems of sustainability of suburban areas rely on the understanding that these spaces are fundamental to the city as a whole. Their condition is reflected in the condition of the agglomeration, while outer areas of the city provide both protective and isolation layer for any supposed transfer of goods, information or people. Suburban areas require not only planning but principal effort of formulating the autonomous strategy. First of all, this zone of the city should be seen as continuum of urban structure, expanding the network of urban connections and interactions, although having its origin in common social concept (M-city) [7, p. 18]. Second, the suburban area is less imprinted by historical evolution of the city, and therefore manifestation of merging global and local tendencies in built environment is here more evident - however at the same time it strongly postulates maintaining identity and both cultural and axiological profile [8].

The qualities of a suburb is determined by various indicators. To name but a few: autonomous economic potential, autonomous social potential, the accessibility and connectivity between local center and city core as well as between local center and adjoining districts including cultural and leisure facilities of various significance (depending on the location), environmental capacity and potential of self-recovery, impact on nearby communities and mutual interactions/influences, among others. Although there are some well-known standards or methodologies to approach the problem of evaluating the sustainability, they strongly depend on the applicable scale, regional specificity, and the evolution of know-how [9, 10]. (Ref [10] summarizes briefly diversity of practices from many places all over the world, related to the evaluation of sustainability.) All these general indicators can be supplemented by extended set of factors, reflecting detailed focus of particular research and evaluation, like in cases of specific component contributing to sustainability. This detailed approach is necessary to enable precise, unambiguous evaluation and unveil real effects of planning or development decisions, leading to self-imposing limitation of sustainability focus, but at the same time allowing for reaching clear objectives of the verification. The general nature of hierarchy of factors must be confronted with locally specific situation of an urban structure [11], and what's more, with cultural context [12, pp. 54-55], which both add to the complexity of establishing the efficient strategy for urban development, particularly within suburban areas, conforming conditions defined for indicators by Weiland [13]. (In ref [12] Evans discusses contradictions between basic inculturation versus gentrification. Cultural context is hereby produced as a resultant of the two merging tendencies and mechanisms to manage them as well as mitigate negative effects.) (The political aspect of spatial management included by Weiland was intentionally skipped.)

\section{Strategy: context and direction}

As a result of the above mentioned problems, suburban areas require not only careful planning, but also establishing the strategy, addressed to formulate long- 
term profile for the development, management and arrangement of particular public spaces. The usual approach observed in Poland, and in other countries as well, indicates that general strategy for agglomeration is treated as required and sufficient document, which is rather problem-specific, not area-specific.

There is a seeming paradox: currently a growing conviction that it is necessary to view urban structure as manifestation of immaterial aspects of urban life interactions between people and between people and sites, actions and transfers, which are not rooted in a particular place despite the fact that they occupy places - confronts the opposite direction in the shift of how strategy should be formulated. But this is neither an accident nor a contradiction. The image of urban structure defined by processes instead of site properties requires site-specific strategy to appropriately plan how site can thrive as viable place to nest users of space, information, transfer nodes - otherwise the network that builds the contemporary city becomes weakened, deteriorates, and disconnects required flows (of people, information and interactions).

Table 1: $\quad$ Policy of balancing spatial management - levels.

\begin{tabular}{|c|c|c|}
\hline \multicolumn{1}{|c|}{ Levels } & \multicolumn{2}{c|}{ Content } \\
\hline Level 1 & \multicolumn{2}{|c|}{$\begin{array}{c}\text { relational level } \\
<\text { coherency> } \\
\text { strategy to strategy }\end{array}$} \\
\hline Level 2 & $\begin{array}{c}\text { global strategy } \\
\text { top-down }\end{array}$ & $\begin{array}{c}\text { local strategy } \\
\text { bottom-up }\end{array}$ \\
\hline Level 3 & urban network & $\begin{array}{c}\text { self-determination (local } \\
\text { identity) }\end{array}$ \\
\hline
\end{tabular}

To be efficient every strategy has to be considered as an element of a threelevel policy. It is important to situate every strategy within the structure of mentioned policy, with its elaboration - necessary context to be respected and reflected within the content of the document. The first level is the relational level. Relational level determines the way global (or general) strategies can connect with local strategies. This connection defines coherency between strategies, the most significant coordination effort to establish verification mechanisms. Data exchange flowing both ways - from the evaluation and the implementation of one strategy to the other - provides necessary procedures aimed at constant adjustment effort. The second level is strategic. Herein depending on the duties of the authorities (or responsible bodies) and needs of particular scale of operation strategy is elaborated to deliver concepts required to manage the urban entity or, in case of local strategy, a component of this entity - district, particular autonomous area. This is a classical combination of two approaches, one topdown; the other bottom-up, to eliminate singular perspective in establishing crucial documents and at the same time crucial decisions for the city. Two ways formulation of strategy, by confronting overall view with the approach of users, acknowledging multiple parties involved, gives all benefits of pluralist cooperation and/or consensual coordination depending on socio-political context [14]. The third level contains the primary guidelines of what aim is to be achieved 
through strategy implementation. While global strategy is aimed at formulating the way the urban entity works, therefore having the purpose of generating wellbalanced urban network, the local one is aimed at distilling the local profile, distinguishing analyzed area from others in the network or working with similarities to understand the nature of transfers between the area examined and other areas.

The usual approach, focused on top-down definition of spatial management, relies on the processes of hierarchization and reduction. Hierarchization, which emerges in every strategy and is required to make it efficient, becomes affected by the process of reduction of local problems, therefore global strategy erases all but the most important local concepts, otherwise making itself too complex document. However the acknowledgement of the role suburban areas play in urban structure requires to initiate parallel process of self-determination, because only based on realization of what constitutes a particular suburban area can sustainable goals and means be decided, and in result - development and management established. Both components, top-down and bottom-up, contribute to the overall image of the future of urban space, with significant focus on cultural issues [15], and thus various (alternative) scenarios may be elaborated and implemented according to the course of events as well as long-term tendencies.

Local strategy - namely, in this paper, strategy for a suburban area - must be situated within that structure. The problem of its coordination with general (or global) strategy for urban network relies on the fact that while local strategy can be elaborated independently, the suburban area cannot function properly "outside" of the network, therefore forcing the process of making local strategy coherent with the city (compare with coordinated management and development criterion - CMD [1, pp. 765-767]). The city, on the other hand, can prosper, develop, maintain its potency, and a particular suburban district is not the prerequisite of its success, but ignoring local goals and needs leads to high risk of incompatibility within urban network endangering its efficiency, with possible negative results surpassing the seeming impact the unbalanced suburb could have on overall structure of the city.

\section{Three strategies for suburban areas}

That being said, one can conclude that while general strategy must work with fragmentary conceptual programs extracted from multiple components of entire urban network, and primarily focuses on proper hierarchization among areas, looking for processes that bind structure together and make it more flexible, adaptive, efficient through activation and synergy of multiple areas, local strategies may concentrate on a particular area, confronting these autonomous goals with external output later on - the scale of the definition of spatial management is so close to the environment (built as well as natural) that there is no further layer to make current perspective blurred. One remark however must be done here - this autonomy does not mean that the process of data analysis can include data, symptoms, and tendencies from the outside of the area - but these are used also to elaborate strategy for that one particular area. 
Establishing urban strategy, in order to conform to requirements of sustainability, follows the framework that implements verification procedures and corresponds to measurable effects (indicators) of sustainability. It is however more difficult to validate cultural components and cultural identity of the area (cultural in its broad sense). Therefore cultural layers must be related to more objectivized components - in this article framework presented by Barelkowski has been taken as referential: reduction of resources consumption (RRC), prioritizing urban development (PUD), adaptability of urban nodes (AUN), integrity of urban tissue (IUT), and proportions among types of spaces (PTS).

The observation of multiple cases, both in Poland and in foreign countries, displays that it is possible to distinguish three main concepts of formulation of suburban strategy. These concepts define the place of the suburb in the urban network by establishing the identity of the area - from subordinate to quasiindependent. Three main and distinct types of suburbs emerge from this kind of analysis, unveiling separate methodologies leading to three various suburban area definitions.

The three strategies are: the strategy of blending, the strategy of reconfiguration, and the strategy of autonomization. The strategy of blending is usually established for background areas of basic city functions (residential, services), monotype or monofunction districts. It focuses on maintaining the flow unaffected, plugging in local users into the urban system. It reflects also the requirement of the city to expand its continual background, feeding areas - places where inhabitants spend significant part of their lives. Blending does not mean that an area cannot maintain its distinct visible features, but surely the issue of identity is to acquire not by means of the meaning of urban space or its function, because function is predominantly far from distinct. Blending strategy aims to find the identity despite the subordinate nature of the area to the city, despite intentional creation of its spatial environment in a way that purposefully does not result in construction of concentrator or strong attractor. This strategy should bring results primarily in IUT, but also RRC, and PUD. The second is strategy of reconfiguration. It is aimed at reinforcing urban structure by unique extension, focus on smart development of urban structure adding urban depth and capacity. The reconfiguration can be understood as a process of transformation of the existing city structure (district) or adding new one, in which case the area is expanded to the point of requiring to gain important impulses or (sometimes and) spatial nodes, sharpening the local identity. This strategy is established to contain transformations necessary to make functions or structures that were unfeasible efficient in economic terms, or it reflects the adjustments in response to failure reports related to significant issues observed within community or area. It is sometimes caused by the urge to adjust to civilization changes or technological changes, but rarely does it facilitate radical change to an existing scheme. Typical districts requiring this type of strategy include mixed-use areas, cultural quarters, creative industry quarters, public space inserts, among others [12, p. 41]. While most often reconfiguration is reaction for a deficit of local identity and aims at improving and strengthening community ties, its objective in spatial terms returns rather a refinement or transformative extension to the area which - in its purpose 
- is locally dependent and, aside of possible attracting of users from outside of the area, anchors constant improvement for local community. Second strategy implementation should be reflected by reductions in resources consumption (RRC) and at the same time provide strong modifying impulse to the structure (PTS). The third strategy is the strategy if autonomization. It is primarily focused on creation unique urban structures providing specialized spaces which cannot be fulfilled within downtown or central districts. Its task is to define appropriate conditions to create remote arrangement of urban structure aimed at establishing limited and spatially detached area, containing autonomous services. These areas should be configured to allow for high rate of adaptability (AUN), and for prioritizing urban development (PUD), not necessarily in the area affected. As it was already mentioned, functions may be related to specialized uses or may refer to large concentration of basic uses (large commercial centers serving the entire urban structure).

\section{Similarities and differences}

All three strategies have to accommodate several groups of indicators in order to fulfill the mission to create balanced environment. The strategy must respond to economic issues, environmental issues, social issues, cultural issues, connectivity issues, spatial form, and interactions. This concept is the extension of several sustainability-related tendencies. First of all, basic domains of sustainability must be represented - this is achieved by the four pillars of sustainability, namely, economy, ecology (environment), society, and culture respected as main fields of influence. But this would be insufficient, because the elaboration requires to be nested within particular conditions which may be represented by physical, solid location only. Thus space that is a place of transfer and transfer itself must by represented in the scheme. And clearly there are interactions between the above mentioned domains, not necessarily affecting directly built environment, but at the same time there are connectivity lines (flow lines), thus material processes (represented by accessibility and connectivity) happening in a particular site.

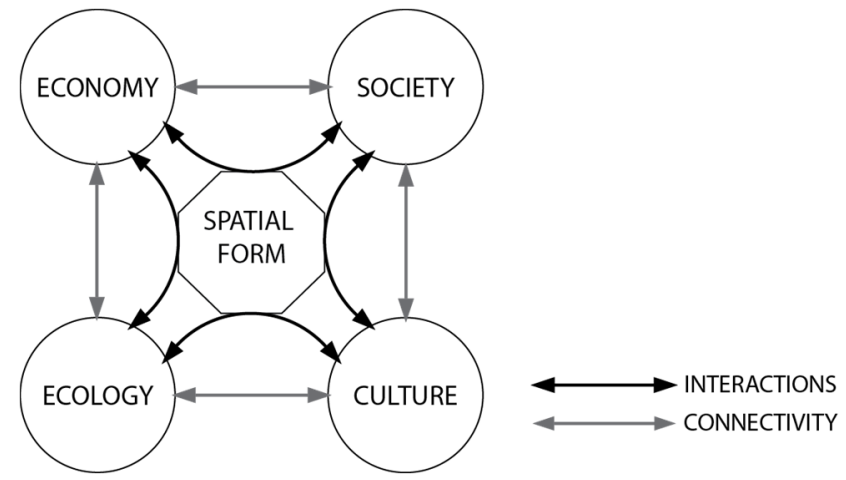

Figure 1: $\quad$ Sustainability in strategy - interpretation scheme. 
This methodological framework provides possible supplementary extensions depending on the specific problems emerging in the area or the city, being the subject of research (or strategy-making). Multiple indicators, or to be more precise groups of indicators, are to be analyzed. While strategies - blending, reconfiguring, and autonomy - have predetermined sets of preferences and are content/context related, several groups of indicators display similar result within certain terrain types. It will be a predominant tendency for strategy of blending to impose the concept of low economic potential, to make districts calm, quiet places to live in for example, in contrary to strategy of autonomy in which commercial district will be activated to serve multiple districts, not only those neighboring. Its vitality will depend on other issues - more on interactions than connectivity. The example of this phenomenon is reflected in research within local communities and their perception of commercial areas - these areas are recognized as symbolic places to go for shopping or to meet other people, but without particular attribution of space, contrary to neighborhood, where imagination of interaction is immediately introduced to physical world, and the representation nominates concrete space to play selected role, convey meanings, allow for processes, etc. What's more, one is unable to specify the autonomous strategy for unique functions on a local level by defining strict physical connections - local strategy is founded on the basis of a particular area limitation and does not extend to the outside world - it is however its task to communicate this aim and influence general strategy of entire urban network.

Table 2 gathers various sustainability indicators and acknowledges rate of their contribution to the final form of the strategy depending on its type. It also reflects the scale of transformations of built environment. The urban form is included as indicator, but its rate of impact is not included due to the fact that spatial urban structure is the result and the manifestation of other elements (see also fig. 1).

The selection of strategy, preliminarily adjusted to the nature of the area immediately indicates several guidelines for the development and management of that area. It stands for a template rather than a norm the shape of built space should compulsory comply to. When set of principal sustainability indicators are determined, they should be reflected in an individualized manner and imprinted on guidelines. Sustainability impact indicators are predetermined, but to establish the content of the strategy four main elements of the profile must be ascribed, reflecting the set of individualized results: identity, mono vs multifunctionality, day cycle, and environmental output (as shown in table 3).

These profiles have been applied in three various areas included in the research. One of the areas is located on the border of city of Poznan (Kiekrz), where district crosses the administrative limits in continual urban structures, primarily composed of detached houses. Another area is located within Poznan (Podolany), in outer zone of the city, where originally industrial zone was located, but due to the transformations in the vicinity manufacturing in the area ceased to be reasonable (e.g. increased problems with heavy transport). The last area is within Greater Poznan limits, but ca. $3 \mathrm{~km}$ outside of city border, the area located among other typical suburban residential developments (Mrowino, Rokietnica). 
Table 2: $\quad$ Sustainability indicators and their impact within particular strategies.

\begin{tabular}{|c|c|c|c|}
\hline $\begin{array}{c}\text { Groups of } \\
\text { indicators/properties/interactions }\end{array}$ & \multicolumn{3}{|c|}{ Strategy (rate of impact) } \\
\hline Strategy type & blending & reconfig & autonom \\
\hline autonomous economic potential & low & avg & high \\
\hline autonomous social potential & high & high & high \\
\hline $\begin{array}{l}\text { accessibility and connectivity } \\
\text { local center }<>\text { city core }\end{array}$ & avg & avg & low \\
\hline $\begin{array}{l}\text { accessibility and connectivity } \\
\text { local center }<>\text { other local centers }\end{array}$ & high & high & low \\
\hline $\begin{array}{l}\text { accessibility and connectivity } \\
\text { local center }<>\text { cultural/leisure/commercial } \\
\text { quarters (nodes) }\end{array}$ & high & high & avg \\
\hline $\begin{array}{l}\text { environmental capacity and potential of self- } \\
\text { recovery }\end{array}$ & low & avg & avg \\
\hline environmental impact & low to avg & avg to high & avg to high \\
\hline $\begin{array}{l}\text { impact on nearby communities - mutual } \\
\text { interactions and influences }\end{array}$ & avg & high & high \\
\hline cultural & low & avg & high \\
\hline (urban) form related - harmonious space & $\mathrm{n} / \mathrm{a}$ & $\mathrm{n} / \mathrm{a}$ & $\mathrm{n} / \mathrm{a}$ \\
\hline (urban) form related - safety & $\mathrm{n} / \mathrm{a}$ & $\mathrm{n} / \mathrm{a}$ & $\mathrm{n} / \mathrm{a}$ \\
\hline (urban) form related - local comfort & $\mathrm{n} / \mathrm{a}$ & $\mathrm{n} / \mathrm{a}$ & $\mathrm{n} / \mathrm{a}$ \\
\hline (urban) form related - adaptability & $\mathrm{n} / \mathrm{a}$ & $\mathrm{n} / \mathrm{a}$ & $\mathrm{n} / \mathrm{a}$ \\
\hline (urban) form related - integrity & $\mathrm{n} / \mathrm{a}$ & $\mathrm{n} / \mathrm{a}$ & $\mathrm{n} / \mathrm{a}$ \\
\hline
\end{tabular}

Table 3: $\quad$ Strategy profile.

\begin{tabular}{|l|l|l|l|l|}
\hline \multicolumn{1}{|c|}{ Profile element } & \multicolumn{1}{|c|}{$\begin{array}{c}\text { Element } \\
\text { interpretation }\end{array}$} & \multicolumn{3}{c|}{ Strategy (rate of impact) } \\
\cline { 3 - 5 } & blending & reconfig & autonom \\
\hline identity (ID) & $\begin{array}{l}\text { meaning/cultural } \\
\text { content }\end{array}$ & low to avg & $\begin{array}{l}\text { avg to } \\
\text { high }\end{array}$ & varied \\
\hline $\begin{array}{l}\text { mono vs } \\
\text { multifunctionality } \\
\text { (SF vs MF) }\end{array}$ & $\begin{array}{l}\text { users } \\
\text { (also proportions } \\
\text { among types of } \\
\text { spaces) }\end{array}$ & $\begin{array}{l}\text { SF } \\
\text { user low } \\
\text { to avg } \\
\text { variety }\end{array}$ & $\begin{array}{l}\text { MF } \\
\text { user avg } \\
\text { to high } \\
\text { variety }\end{array}$ & $\begin{array}{l}\text { SF/MF } \\
\text { users } \\
\text { varied }\end{array}$ \\
\hline day cycle (DC) & program/flow & $\begin{array}{l}2 / 3 \\
\text { simple }\end{array}$ & $\begin{array}{l}\text { full } \\
\text { complex }\end{array}$ & $\begin{array}{l}1 / 3 \\
\text { avg to } \\
\text { complex }\end{array}$ \\
\hline $\begin{array}{l}\text { environmental output } \\
\text { (EO) }\end{array}$ & $\begin{array}{l}\text { parametric } \\
\text { performance (e.g. } \\
\text { emissions) }\end{array}$ & $\begin{array}{l}\text { general } \\
\text { guidelines } \\
\text { to } \\
\text { individual } \\
\text { users }\end{array}$ & $\begin{array}{l}\text { mixed } \\
\text { guidelines }\end{array}$ & $\begin{array}{l}\text { guidelines } \\
\text { focused } \\
\text { on special } \\
\text { function } \\
\text { perform- } \\
\text { ance }\end{array}$ \\
\hline
\end{tabular}

Mrowino is a place to implement the strategy of blending. The existing urbanized structure already exists, mainly due to the imperative to control the cultural impact - connection between new development and existing ones. Despite adjustments related to the insertion of commercial functions (low amount of mixed function areas), Mrowino development is seen as a place to blend in the environment. 
Kiekrz is a specific area, divided by the border of the city. One part is oriented towards more rural landscape, yet retains villa-type or detached house type character. At the same time, the other part remaining within the city limits has only slightly more larger houses and fewer service buildings.

Podolany area is partially abandoned former industrial area, randomly mixed with singular residential objects. It is located within $6-7 \mathrm{~km}$ distance from the center, just behind the greening ring of former Prussian fortifications from $19^{\text {th }}$ century. Its heavily imprinted industrial character eliminates or at least discourages the district (part being subject of research) to become residential area. Strategy aims at finding new concept for the area, therefore reforges its new identity by formulating a postulate of working space hub - offices, administration mixed with supplementary commercial places.

Table 4: $\quad$ Strategy profile.

\begin{tabular}{|c|c|c|c|}
\hline Area no. & Area 1 & Area 2 & Area 3 \\
\hline Area name & Mrowino & Kiekrz & Podolany \\
\hline Strategy & blending & reconfiguration & autonomization \\
\hline $\begin{array}{l}\text { Neighboring } \\
\text { structures }\end{array}$ & housing & housing & housing, industrial \\
\hline Users & low variety & avg variety & low variety \\
\hline Program & $\begin{array}{l}\text { housing (few } \\
\text { commercial sites) }\end{array}$ & $\begin{array}{l}\text { mixed-use }> \\
\text { commercial, retail, } \\
\text { offices, admin., } \\
\text { residential }\end{array}$ & $\begin{array}{l}\text { workplace creation }> \\
\text { offices, administration, } \\
\text { commercial }\end{array}$ \\
\hline $\begin{array}{l}\text { Parametric } \\
\text { performance }\end{array}$ & insignificant increase & significant increase & significant increase \\
\hline $\begin{array}{l}\text { Instrumentalization } \\
\text { of planned solutions } \\
\text { (priorities) }\end{array}$ & $\begin{array}{l}\text { integrity (IUT) } \\
\text { reduction (RRC) }\end{array}$ & $\begin{array}{l}\text { proportion (PTS) } \\
\text { reduction (RRC) }\end{array}$ & adaptability (AUN) \\
\hline RRC & densification & $\begin{array}{l}\text { providing basic } \\
\text { services at } \\
\text { comfortable distance }\end{array}$ & $\mathrm{n} / \mathrm{a}$ \\
\hline PUD & $\mathrm{n} / \mathrm{a}$ & $\mathrm{n} / \mathrm{a}$ & attractiveness \\
\hline AUN & $\begin{array}{l}\text { restrained to existing } \\
\text { functions, functional } \\
\text { standards }\end{array}$ & & $\begin{array}{l}\text { mutating spaces, } \\
\text { temporary functions, } \\
\text { re-configured spaces, } \\
\text { high quality core }\end{array}$ \\
\hline IUT & consolidation & maintaining & converting refurbishing \\
\hline PTS & $\mathrm{n} / \mathrm{a}$ & $\begin{array}{l}\text { balancing through } \\
\text { changes in spatial } \\
\text { structure }\end{array}$ & dynamic conversions \\
\hline Identity & $\begin{array}{l}\text { cultural content is } \\
\text { defined by: } \\
\text { - unification of housing, } \\
\text { - implementation of few } \\
\text { commercial points, } \\
\text { - planning for } \\
\text { extensions of existing } \\
\text { public spaces. }\end{array}$ & $\begin{array}{l}\text { cultural content is } \\
\text { defined by: } \\
\text { - introduction of } \\
\text { multiple public } \\
\text { functions, } \\
\text { - providing commercial } \\
\text { objects for close and } \\
\text { more distant districts, } \\
\text { - adding cultural } \\
\text { program. }\end{array}$ & $\begin{array}{l}\text { cultural content is } \\
\text { defined by: } \\
\text { - transformation of } \\
\text { industrial zone into } \\
\text { office area, } \\
\text { - implementing public } \\
\text { space, } \\
\text { - involving } \\
\text { cultural program to } \\
\text { increase social impact. }\end{array}$ \\
\hline
\end{tabular}


To build the identity of those three places, different strategies selected use diverse means resultant of the choice. While Mrowino unifies urban tissue giving the continuity of residential zone, and - due to density of the area (including the inhabitants) - rather contributing to existing public spaces, than creating new ones, in Kiekrz large amount of the same tissue devoid of commercial space required to be remodeled and supplemented with local center, becoming a new yet coherent element of local identity, expected and required by the local community. Podolany area (analyzed part of the quarter) is an isolated place and it has good connection to adjacent roads. Case studies, impossible to be presented in extenso in the paper, display the level of viability of strategies, with some immediate results, particularly within the area of Kiekrz, where community demand has been met in a very sufficient way, at the same time giving mostly sustainability in accessibility and social aspects of the district.

\section{Conclusions: towards embedding cultural content}

While the decision on the physical shape of the built environment may not lie as early as during elaboration of the strategy, and the quality of human life is eventually decided when those physical parameters are finally established, strategy is responsible for giving rightful foundations to those resultant decisions. First, a society, or to be more specific, a community must be seen in context of space use and management. Not as a static group of users, but of course as dynamic, changing group of diversified origin and different preferences. It is quite clear that strategy helps in selecting proper match between area and community, but current methodologies are lacking extensive feedback, which is necessary to understand complexity of local area in grander document of strategy for whole city. Therefore strategies for suburban areas seem to be fruitful.

Using cultural content in urban space brings more to the built environment than just infrastructure and spaces to be culturally contained. Identity is the trigger to initiate the effect of synergy, achieved by the combination of local actions, namely local strategy, elaborated in coordination with general strategy, but with allowed autonomy, improvement of joint use of two data flow streams within pre-planning and planning processes which will result in better synergy between results of topdown planning and bottom-up planning efforts performed with local community participation, finally in extension of the process of evaluation by multiplying the amount of simultaneous and active evaluation by parties interested in the quality of space. The latter - multiplying sources of critical/analytical information makes feedback particularly important and enriching mechanism.

Presented taxonomy of strategies serves the purpose of better understanding the aims of pre-planning and planning processes. It also displays part of considerations undertaken while researching the evolution of the suburban area of Poznan, with particular interest directed towards North-West direction of expansion - towards Rokietnica and Oborniki. The work is also intended to advocate for problem-solving planning with targeted planning (long-term perspective aim-driven). Planning can and should convey cultural message particular that, again, can become continuous and timeless in its goal to achieve 
sustainable solutions, without losing the potential to modernize human environment, but with respect paid to all existing and valuable components.

\section{References}

[1] Barelkowski, R.: 2012, The Edge of the [dis]Order, in M. Pacetti, G. Passerini, C. A. Brebbia, G. Latini (eds.) The Sustainable City VII. Urban Regeneration and Sustainability, Wessex Institute of Technology, WIT Press, Southampton \& Boston, 759.

[2] Bruegmann, R.: 2000, The Paradoxes of Anti-Sprawl Reform, in R. Freestone (ed.), Urban Planning in a Changing World, 162-166.

[3] Smas, L.: 2009, Consumption through a City Quarter: Changes and Continuities, in M. Legnér and D. Poznini (eds.), Cultural quarters and Urban Transformation: International Perspectives, Gotlandica Förlag, Klintehamn, 295-296.

[4] Paddison, R.: 2009, Public Art and Urban Cultural Regeneration: Reaching to the Local Community, in M. Legnér and D. Ponzini (eds.), Cultural quarters and Urban Transformation: International Perspectives, Gotlandica Förlag, Klintehamn, 245-246.

[5] Savitch, H. V.: 2003, How Suburban Sprawl Shapes Human Well-Being, Journal of Urban Health, Vol. 80, No. 4, Dec 2003, 590-607.

[6] Marshall, R.: 2004, Asian Megacities, in R. El-Khoury and E. Robbins (eds.), Shaping the City. Studies in History, Theory and Urban Design, Routledge, New York, 207-208.

[7] Barelkowski, R.: 2010, Against the Rules, Architectural Volumes: The Faces of Urbanized Space, 1/2010, 17-22.

[8] Heberle, L. C.: 2008, Sustainable Urban Development: Local Strategies as Global Solutions, in L. C. Heberle and S. M. Opp (eds.), Local Sustainable Urban Development in a Globalized World, Ashgate, Aldershot, 1-8.

[9] Colantonio, A. and Dixon, T.: 2009, Measuring Socially Sustainable Urban Regeneration in Europe, Oxford Institute for Sustainable Development, School of the Built Environment, Oxford Brookes University, Oxford.

[10] SCI-Indicators: 2012, Indicators for Sustainability. How cities are monitoring and evaluating their success, Sustainable Cities International, Vancouver.

[11] Chakraborty K.: 2008, A Methodology to Measure Indicators of Urban Sustainable Development in India: Case Study Bangalore, Centre for Infrastructure, Sustainable, Transportation, and Urban Planning, IISc, 16.

[12] Evans, G. L.: 2009, Form Cultural Quarters to Creative Clusters - Creative Spaces in the New City Economy, in M. Legnér and D. Ponzini (eds.), Cultural quarters and Urban Transformation: International Perspectives, Gotlandica Förlag, Klintehamn.

[13] Weiland, U.: 2006, Sustainability Indicators and Sustainable Development, in W. Wuyi, T. Krafft, and F. Kraas (eds.), Global Change, Urbanization and Health, China Meteorological Press, Beijing, 243-244. 
[14] Kantor, P.: 2012, Assessing the Governance Capacity of Metropolitan Areas: A Comparative Perspective, Governing the Metropolis, Mairie de Paris Conference, 28-30 Nov, 2012, 7-8, 10-12.

[15] Grodach, C. and Loukaitou-Sideris A.: 2007, Cultural Development Strategies and Urban Revitalization. A survey of US cities, International Journal of Cultural Policy, Vol. 13, No. 4, 349-370. 